\title{
Washington, we have a problem
}

\author{
Does anybody care about NASA? Most in Congress do only if there is a research centre in their district. \\ David Goldston explains why members never step up to the plate to set priorities.
}

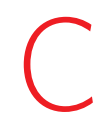

ongress is facing some tough issues as it begins to figure out NASA's budget for the next fiscal year. A new report from the National Academy of Sciences decries the state of Earth sciences at the US space agency; NASA claims that congressional trims to its current budget for human spaceflight will delay the debut of its Orion spaceship; and the Bush administration is proposing deep cuts in the agency's aeronautics budget for next year. What is Congress likely to do?

Probably the usual - just kick the can down the road a bit. Congress often alters the proposed NASA budget, but it rarely, if ever, manages to make fundamental decisions about what the agency's priorities should be. That's why NASA so often looks like it is carrying a broad portfolio of programmes, all of them seeming as though they are on life support.

There are basic institutional reasons for this ongoing paralysis, and they're unlikely to change any time soon. Very few in Congress pay much attention to NASA, and those who do tend to have fierce loyalties to just one aspect of the agency's activities. As a result, most efforts to set clear priorities end in stalemate.

The most active members of Congress generally represent NASA facilities, and they work to protect their centre's budget and jobs. To take some obvious examples, Senator Kay Bailey Hutchison (Republican, Texas) throws her weight behind the human spaceflight programme to ensure that Houston doesn't have a problem. And Senator Barbara Mikulski (Democrat, Maryland) watches out for her state's Goddard Space Flight Center.

That's not to say that policy plays no role in debates. Congress has shown strong support for NASA's aeronautics programmes because aviation is seen as critical to US competitiveness and because it has been a key NASA responsibility from its inception in 1958. Led by members representing NASA's aviation centres, such as Representative Frank Wolf (Republican, Virginia), Congress has often rejected steep cuts in aeronautics even though the aviation industry has barely lifted a finger on behalf of the programmes. (Industry may be reluctant to alienate NASA leadership over aeronautics when it has far more money riding on human spaceflight programmes, and NASA is shifting its emphasis away from the industry favourites, demonstration programmes.) The

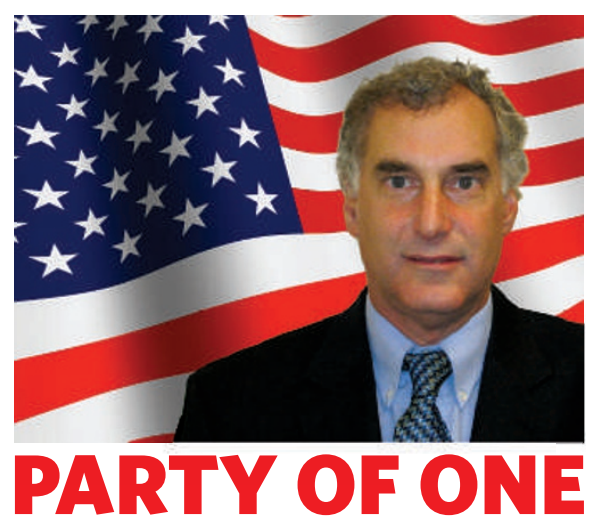

result is that aeronautics funding has declined, but at a slower rate than proposed, leaving NASA in a kind of limbo: aeronautics lacks the money for its programmes to thrive, but it still consumes dollars that NASA's leaders want to shift into higher-priority areas.

Note that none of these NASA issues breaks along partisan lines. President George W. Bush's lunar mission raised howls equally from liberal Democrats, who thought the money ought to be spent on Earth, and conservative Republicans, who thought that government ought not spend so much money, period. But the whole matter was quickly forgotten by most.

So the story one hears now from most members of Congress, and some in the media, is that the president made a speech about going to Mars in 2004, got nothing but grief for it, and the proposal went nowhere. This is, of course, almost entirely wrong. The bottom line of the president's speech was to return astronauts to the Moon by 2020 . That programme has been going forward steadily (see Nature 445, 474478 ; 2007), albeit with less funding than originally proposed. The president's silence has been, if anything, a strategic retreat that has actually hastened plans for a lunar mission - because few other than NASA's most ardent supporters in Congress are paying much attention.

Congress had a chance to debate NASA's future in 2005, when it considered a bill to reauthorize the agency. Authorization bills don't provide funding; they set policies and lay out Congress's multi-year intentions for an agency. The bill dealt only with NASA, unlike spending bills where NASA money is part of a package that includes funding for unrelated agencies.

The bill, as usual, reflected the congressional stalemate. It both endorsed the lunar mission and explicitly required NASA to continue funding aeronautics, and Earth and space science. It indicated that more money than the president was proposing would be needed to continue all those activities effectively, and it implicitly endorsed the president's plan to retire the space shuttle in 2010 - which Texas and Florida representatives had considered blocking. (As chief of staff of the House Committee on Science, I helped write and move the bill.)

No bill that made tougher choices had a prayer of making it through the committee stage in either the House or Senate. And in any event, Tom DeLay (Republican, Texas), who was then House majority leader, would have prevented any bill that failed to endorse the lunar mission from coming before the House. When the bill did come up, there was virtually no debate. The only member in the House who spoke against it was a liberal Democrat, Barney Frank (Massachusetts), who said the human "mission to Mars" was a waste of money.

The inattention of Congress mirrors that of the public. Members of Congress hear from very few constituents about NASA unless they represent NASA employees. Polls, depending on how they are worded, can show strong public support for human spaceflight or little, which was true even in the Apollo era.

The one time in recent memory that Congress heard something of a public response to a NASA decision was when the agency announced (or rather, let seep out) that it was cancelling the mission to extend the life of the Hubble Space Telescope. I even heard a waiter in the congressional dining room tell then-NASA administrator Sean O'Keefe to "save that Hubble".

As the public objected, Congress held hearings and made noises about reversing the decision. But it was in a tough position because O'Keefe had claimed that the decision was meant, in the wake of the Columbia disaster, to reduce the risk to shuttle astronauts visiting Hubble. Congress was also reluctant to override what was an operational, as well as a policy decision. So paralysis again seemed the order of the day. It took the new NASA administrator, Michael Griffin - not Congress - to break the logjam by reversing the decision altogether.

David Goldston is a visiting lecturer at Princeton University's Woodrow Wilson School of Public and International Affairs. 